\title{
Viscoelastic cannula acting as a wrecker and saviour during cataract surgery
}

\author{
Saumya Yadav, Radhika Tandon, ${ }^{\ominus}$ Rashmi Singh, Amar Pujari ${ }^{\odot}$
}

Department of Ophthalmology, Dr. Rajendra Prasad Centre for Ophthalmic Sciences, All India Institute of Medical Sciences, New Delhi, India

\section{Correspondence to \\ Dr Saumya Yadav,} dr.sy17@gmail.com

Accepted 31 July 2019

\section{DESCRIPTION}

A 62-year-old male patient was planned for left eye phacoemulsification with premium intraocular lens (IOL) implantation under topical anaesthesia. His preoperative best corrected visual acuity (BCVA) was 6/24 in left eye and there was no evidence of any other abnormality apart from cataract. During initial steps of phacoemulsification, after making two side port entries with a 20 gauge micro-vitreoretinal blade, a cohesive ophthalmic viscosurgical device was injected using a 27 gauge cannula fitted with a luer-lock syringe system. A tight fit of cannula was confirmed by surgeon before injection and the hub of the needle was supported while injecting. During injection, the viscoelastic cannula abruptly shot off from the syringe in a projectile fashion and impacted the lens causing $360^{\circ}$ zonular dehiscence (video 1). After an immediate careful assessment it was found that the cannula was passing through full thickness of lens (figure 1) thus acting as anchor. Seeing that the cannula was actually preventing posterior dislocation of lens, it was not withdrawn from eye and for meanwhile, was left as such. As cataract removal was not possible now using phacoemulsification technique, the surgery was converted into an intracapsular cataract extraction via superior approach. Till the time of delivery of lens, the viscoelastic cannula was held in place by assistant and was used as an anchor at time of delivery. A limited anterior vitrectomy was performed and the patient was left aphakic. On postoperative day 1 , patient had minimal corneal oedema, media was clear and fundus evaluation did not show evidence of retinal damage. As the patient did not consent for scleral fixated IOL and iris fixation is not our routine practice, secondary implantation of an anterior chamber IOL was performed 7 weeks later (figure 2). The patient achieved a BCVA of $6 / 6$ recorded at 6 months follow-up.

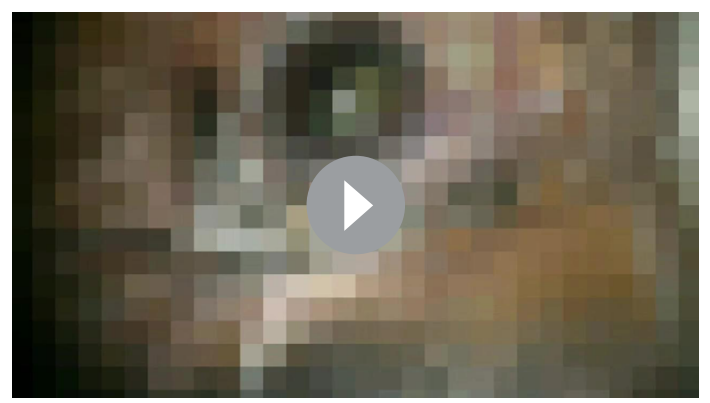

Video 1 Video clip demonstrating the critical steps of surgery.

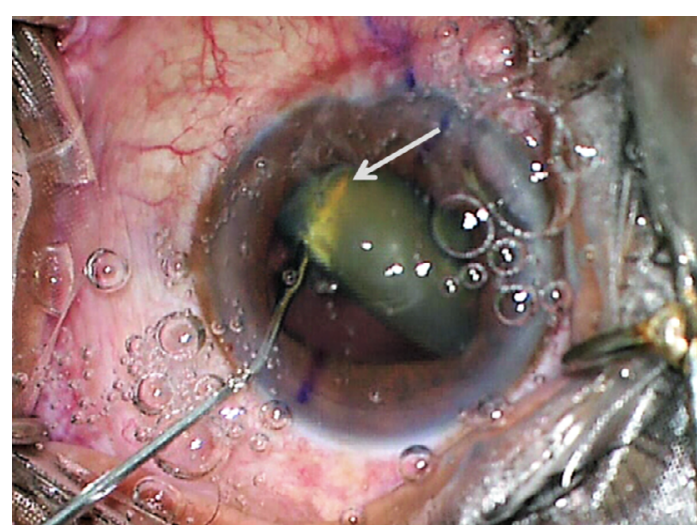

Figure 1 Viscoelastic cannula can be seen passing through full thickness of lens (white arrow) causing $360^{\circ}$ zonular dialysis.

Reported incidence of cannula dislodgement during cataract surgery is $0.009 \%{ }^{1}$ to $0.07 \%$. $^{2}$ Although rare, an inadvertent release of cannula can result in drastic complications in an otherwise routine cataract surgery. An array of intraocular injuries like iris damage, ${ }^{3}$ cyclodialysis cleft with chronic hypotony, ${ }^{4}$ vitreous haemorrhage and retinal tears leading to retinal detachment ${ }^{5}$ have been reported. In our case, we were lucky that despite of such forceful nature of injury no other intraocular structure was damaged. The cannula did act as a saviour afterwards and prevented the need of further vitreoretinal intervention.

A schematic stepwise approach has been recommended for prevention of cannula associated injuries. ${ }^{3}$ Luer-lock syringes have a screw like arrangement and if misaligned, cannula gets jammed during the initial turns giving a false impression of tight fit. If surgeon/nurses are unaware of this, the

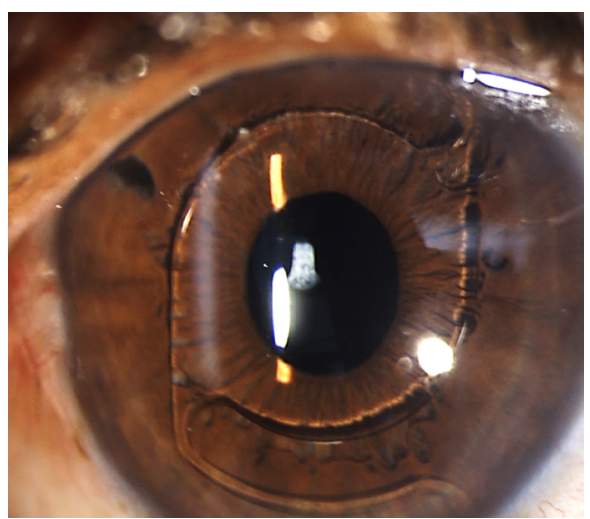

Figure 2 Slit lamp photograph at 6 months follow-up showing an anterior chamber intraocular lens in situ. 


\section{Learning points}

- Cannula associated ocular injury, although rare, can result in devastating complications requiring multiple interventions.

- Appropriate pre-emptive measures must be taken to prevent its occurrence, and both the surgeon and the nurse should be cognisant with proper cannula placement technique.

- Despite precautions, cannula injuries do occur and in such scenarios a diligent management of the complications by the surgeon becomes the key factor in determining postoperative outcomes.

increased pressure during injection may release at the weakest point, that is insecurely attached cannula causing it to shoot-off, as might have happened in our case. This case highlights the importance of being on guard throughout surgery with rapid assessment of complications created by untoward happenings and their suitable surgical correction. This is a rare and unique variation of cannula associated ocular injury managed suitably with good visual outcome.
Contributors SY, RS and AP were involved in conception, design and preparation of the manuscript. RT played a key role in critical revision and preparation of final version of the manuscript.

Funding The authors have not declared a specific grant for this research from any funding agency in the public, commercial or not-for-profit sectors.

Competing interests None declared.

Patient consent for publication Obtained.

Provenance and peer review Not commissioned; externally peer reviewed.

\section{REFERENCES}

1 Ting DS, Vaideanu-Collins D, Ellerton C. Cannula-associated ocular injuries during cataract surgery: the North East England Study. Eye 2016;30:764-5.

2 Rumelt $\mathrm{S}$, Kassif Y, Koropov M, et al. The spectrum of iatrogenic intraocular injuries caused by inadvertent cannula release during anterior segment surgery. Arch Ophthalmol 2007;125:889-92.

3 Ting DSJ, Dees C, Ellerton C. Cannula-associated ocular injuries during cataract surgery: a preventable intraoperative complication? Middle East Afr J Ophthalmol 2017;24:54-6.

4 Kahawita S, Cugati S, Casson R. Cyclodialysis cleft with late hypotony maculopathy after inadvertent cannula detachment during cataract surgery. J Cataract Refract Surg 2015;41:1107-8.

5 Prenner JL, Tolentino MJ, Maguire AM. Traumatic retinal break from viscoelastic cannula during cataract surgery. Arch Ophthalmol 2003;121:128-9.

Copyright 2019 BMJ Publishing Group. All rights reserved. For permission to reuse any of this content visit

https://www.bmj.com/company/products-services/rights-and-licensing/permissions/

BMJ Case Report Fellows may re-use this article for personal use and teaching without any further permission.

Become a Fellow of BMJ Case Reports today and you can:

- Submit as many cases as you like

- Enjoy fast sympathetic peer review and rapid publication of accepted articles

- Access all the published articles

Re-use any of the published material for personal use and teaching without further permission

Customer Service

If you have any further queries about your subscription, please contact our customer services team on +44 (0) 2071111105 or via email at support@bmj.com.

Visit casereports.bmj.com for more articles like this and to become a Fellow 